\title{
The origin of fibrin breakdown products and the interpretation of their appearance in the circulation
}

\author{
M. J. GALLIMORE, H. M. TYLER, AND J. T. B. SHAW \\ From the Research Division, Pfizer Ltd, Sandwich, Kent, England
}

SYNOPSIS It has been shown that the incubation of human plasma with urokinase at a concentration sufficient to cause rapid lysis of the clots formed on the addition of thrombin does not give rise to the production of measurable concentrations of non-clottable fibrinogen breakdown products. Also, breakdown products could not be detected in the course of experiments in vivo when urokinase was administered to monkeys and only in very low concentrations when a fibrinolytic state was induced by exercise in three healthy human volunteers. In contrast, high concentrations of breakdown products were found after thrombin infusion into monkeys.

It is concluded that circulating fibrinogen is not readily broken down into non-clottable products by the fibrinolytic enzymes, and that normal animals and healthy human subjects do not have substantial deposits of fibrin that are available for breakdown during a fibrinolytic episode. The presence of breakdown products in the circulation is therefore likely to be indicative of the fibrinolytic response to an initial coagulation event.

The appearance in the circulation of raised concentrations of non-clottable substances derived from fibrin or fibrinogen which are capable of agglutinating with anti-fibrinogen antiserum is widely regarded as an established feature of a fibrinolytic state in human subjects. Such an effect has been observed following exercise or the administration of adrenaline (Das, Allan, Woodfield, and Cash, 1967), in a variety of pathological conditions (Thomas et al, 1970), and, most dramatically, in patients with a defibrination syndrome (Ferreira and Murat, 1963; Merskey, Kleiner, and Johnson, 1966; Bonnar, Davidson, Pidgeon, McNicol, and Douglas, 1969).

Although the non-clottable products of fibrinolytic activity in vivo are commonly referred to as fibrin breakdown products, the nature of the available assays does not permit discrimination between polypeptides deriving from fibrin and those deriving from fibrinogen, and there is at present no clear evidence to establish their origin. The question is of some importance, for while the induction of a fibrinolytic state is clearly desirable in the treatment of thrombotic disease, fibrinogenolysis, if severe or prolonged, could well be disadvantageous.

The evidence as to whether breakdown products appear in the plasma of normal subjects as a result of the induction of a fibrinolytic state is equivocal. Received for publication 4 August 1971.
Studies of the effects of phenformin-ethyloestrenol combinations in normal subjects and in rheumatoid patients led Fearnley, Chakrabarti, and Evans (1969) to conclude that the raised concentrations of breakdown products that they found in both groups were the result of the proteolysis of fibrin deposits rather than of circulating fibrinogen. They also commented that the available evidence indicates that fibrinogenolysis is encountered only in states of pathological fibrinolytic activity. In contrast to Fearnley's observations, Gormsen and Vad (1970) were unable to detect increased breakdown products in the plasma of normal subjects whose fibrinolytic activity had been raised by the administration of phenformin and ethyloestrenol and by other agents, including nicotinic acid.

In this paper, evidence is presented which supports the view that the polypeptides measured as breakdown products in the serum following the stimulation of fibrinolysis are the products of fibrin breakdown, and that the breakdown of fibrinogen to non-clottable fragments is likely to be encountered only in exceptional circumstances.

\section{Materials and Methods}

Plasminogen-rich bovine fibrinogen was prepared by fractional precipitation from plasma fraction I 
(Armour Laboratories, Eastbourne, England) according to a procedure described earlier (Gallimore and Shaw, 1967).

Thrombin (bovine, $5000 \mathrm{NIH}$ units/ampoule) and urokinase (reference standard, 2340 Ploug units/ampoule) were obtained from Leo Laboratories, Hayes, Middlesex, England.

Soya-bean trypsin inhibitor, $3 \times$ crystallized, was purchased from California Biochemicals, Los Angeles, USA.

Fi-test (latex particles coated with antihuman fibrinogen antiserum) was supplied by Hyland Division, Travenol Laboratories, Inc, Costa Mesa, California, USA.

Tris-(hydroxymethyl)-methylamine (Tris) was obtained from BDH Ltd, Poole, Dorset, England.

6-Aminocaproic acid (EACA) was bought from Koch-Light Laboratories, Colnbrook, Bucks, England.

Sernylan (phencyclidine hydrochloride) was purchased from Parke, Davis \& Company, Hounslow, London, England.

Tris- $\mathrm{HCl}$ buffer, $p \mathrm{H} 7 \cdot 4,0 \cdot 1 \mathrm{M}$, was prepared by dissolving $12.1 \mathrm{~g}$ of the base in water, adjusting the $p \mathrm{H}$ to $7 \cdot 4$ with $1 \mathrm{~N}-\mathrm{HCl}$ and the volume to 1 litre.

Other reagents were of Analar grade.

\section{RHESUS MONKEYS}

Rhesus monkeys (Macaca mulatta) were young males, weighing 3-5 kg, purchased from Shamrock Farms (Great Britain) Ltd, Henfield, Sussex, England.

\section{BLOOD AND PLASMA}

Venous blood was withdrawn from human subjects into plastic syringes. For the collection of blood samples from monkeys, the animals were immobilized with Sernylan $(4 \mathrm{mg} / \mathrm{kg}$ im). Blood was then withdrawn into a plastic syringe from a femoral vein. When sequential blood samples were required, the animal was cannulated via a saphenous vein; a slow intravenous drip was instituted in order to prevent clotting within the cannula, and blood was withdrawn through a three-way tap by a two-syringe technique. After withdrawal, blood was immediately transferred to a plastic container standing in crushed ice.

When plasma was required, the blood was mixed with 1/9 volume of aqueous trisodium citrate dihydrate $(3.8 \% \mathrm{w} / \mathrm{v})$; platelet-poor plasma was then obtained by centrifugation at $3000 \mathrm{~g}$ for 20 minutes.

\section{DILUTE BLOOD CLOT LYSIS}

The assays of dilute blood clot lysis times were performed by adding $0.2 \mathrm{ml}$ of blood (immediately after collection) to $1.8 \mathrm{ml}$ of $0.12 \mathrm{M}$ sodium acetate solution adjusted to $p \mathrm{H} 7 \cdot 4$ containing 2.5 units of thrombin; trisodium citrate dihydrate $(360 \mu \mathrm{g} / \mathrm{ml})$ was included in the diluent used with human blood. After mixing the samples were incubated at $37^{\circ}$, and the clot lysis times were measured; all estimations were performed in duplicate. Details of the procedure are given by Gallimore and Shaw (1969).

\section{FIBRIN BREAKDOWN PRODUCTS}

The estimation of fibrin breakdown products in blood was performed by the following modification of a method of Merskey et al (1966). Samples of blood, each of $0.9 \mathrm{ml}$, were transferred to tubes containing $0 \cdot 1 \mathrm{ml}$ of a solution of soya bean trypsin inhibitor $(50 \mu \mathrm{g})$ and thrombin (2.5 units) in Tris$\mathrm{HCl}$ buffer. After standing for two hr at room temperature and at $+2^{\circ}$ overnight, the clots were centrifuged and the sera collected. For the estimation of fibrin breakdown products, serial dilutions of the sera from $1 / 2$ to $1 / 3200$ were prepared in Tris- $\mathrm{HCl}$ buffer. Approximately $20 \mu \mathrm{l}$ of each solution was introduced into a capillary tube together with $20 \mu$ l of Fi-test reagent; the tubes were then rocked for five min to mix the contents, and were inspected for latex aggregation. From the maximum dilution of the serum producing aggregation it is possible to calculate the concentration of fibrin breakdown products by comparison with standard dilutions of human and monkey plasma samples containing known amounts of fibrinogen. The quantitative expression of the results of the assay rests on the unsubstantiated assumption that fibrinogen and fibrin breakdown products cause equal aggregation at equal concentrations. Thus, although valid comparisons can be made between serum samples from the same species, some doubt exists as to the absolute values assigned to fibrin breakdown product concentrations. A similar procedure for determining fibrin breakdown products has recently been described in some detail by Melliger (1970).

\section{Experimental}

BREAKDOWN OF PLASMA CLOTS AND OF PLASMA FIBRINOGEN BY UROKINASE

To $0.30 \mathrm{ml}$ aliquots of human or Rhesus monkey plasma were added various amounts of urokinase dissolved in Tris-HCl buffer, and sufficient of the same buffer to bring the volume to $0.45 \mathrm{ml}$. Clots were formed by the addition of $0.05 \mathrm{ml}$ of thrombin solution $(200 \mathrm{u} / \mathrm{ml})$; these were incubated at $37^{\circ}$ and the lysis times were recorded. Further $0.30 \mathrm{ml}$ portions of the same plasmas were then incubated at $37^{\circ}$ for various times with the same amounts of urokinase, the total volume again being made to 


\begin{tabular}{|c|c|c|c|c|c|c|c|c|c|c|c|}
\hline \multicolumn{4}{|c|}{ Human Plasma } & \multicolumn{4}{|c|}{ Rhesus Monkey Plasma } & \multicolumn{4}{|c|}{ Bovine Fibrinogen ${ }^{1}$} \\
\hline $\begin{array}{l}\text { Urokinase } \\
\text { Added } \\
\text { (units) }\end{array}$ & $\begin{array}{l}\text { Clot } \\
\text { Lysis } \\
\text { Time } \\
\text { (min) }\end{array}$ & $\begin{array}{l}\text { Plasma } \\
\text { Incubation } \\
\text { Time } \\
\text { (min) }\end{array}$ & $\begin{array}{l}\text { Clotting } \\
\text { Time } \\
\text { (sec) }\end{array}$ & $\begin{array}{l}\text { Urokinase } \\
\text { Added } \\
\text { (units) }\end{array}$ & $\begin{array}{l}\text { Clot } \\
\text { Lysis } \\
\text { Time } \\
\text { (min) }\end{array}$ & $\begin{array}{l}\text { Plasma } \\
\text { Incubation } \\
\text { Time } \\
\text { (min) }\end{array}$ & $\begin{array}{l}\text { Clotting } \\
\text { Time } \\
\text { (sec) }\end{array}$ & $\begin{array}{l}\text { Urokinase } \\
\text { Added } \\
\text { (units) }\end{array}$ & $\begin{array}{l}\text { Clot } \\
\text { Lysis } \\
\text { Time } \\
\text { (min) }\end{array}$ & $\begin{array}{l}\text { Fibrinogen } \\
\text { Solution } \\
\text { Incubation } \\
\text { Time } \\
\text { (min) }\end{array}$ & $\begin{array}{l}\text { Clotting } \\
\text { Time } \\
\text { (sec) }\end{array}$ \\
\hline 16 & $23 \cdot 1$ & $\begin{array}{l}10 \\
20 \\
60\end{array}$ & $\begin{array}{l}<20 \\
<20 \\
<20\end{array}$ & 45 & $9 \cdot 0$ & $\begin{array}{l}10 \\
20 \\
60\end{array}$ & $\begin{array}{l}<20 \\
<20 \\
<20\end{array}$ & 3 & $19 \cdot 2$ & $\begin{array}{l}10 \\
20 \\
30\end{array}$ & $\begin{array}{l}<20 \\
>60^{2} \\
\text { N.C. }\end{array}$ \\
\hline 40 & $8 \cdot 2$ & $\begin{array}{l}10 \\
20 \\
60\end{array}$ & $\begin{array}{l}<20 \\
<20 \\
\sim 30^{2}\end{array}$ & 75 & $6 \cdot 0$ & $\begin{array}{l}10 \\
20 \\
60\end{array}$ & $\begin{array}{l}<20 \\
<20 \\
\sim 20\end{array}$ & 5 & $14 \cdot 8$ & $\begin{array}{r}5 \\
10 \\
20\end{array}$ & $\begin{array}{l}<20 \\
<20 \\
\text { N.C. }\end{array}$ \\
\hline 80 & $4 \cdot 5$ & $\begin{array}{l}10 \\
20 \\
60\end{array}$ & $\begin{array}{l}<20 \\
<20^{2} \\
\sim 60^{2}\end{array}$ & 150 & $4 \cdot 0$ & $\begin{array}{l}10 \\
20 \\
60\end{array}$ & $\begin{array}{l}<20 \\
<20 \\
\sim 20\end{array}$ & 10 & $10 \cdot 0$ & $\begin{array}{r}5 \\
10 \\
20\end{array}$ & $\begin{array}{r}<20 \\
30^{2} \\
\text { N.C. }\end{array}$ \\
\hline
\end{tabular}

Table I Comparison of the rates of proteolysis of fibrin and of fibrinogen by combinations of urokinase and plasminogen in plasma and in purified systems

${ }^{1}$ Very similar results were subsequently obtained in similar assays with plasminogen-rich human fibrinogen 'Weak clot

N.C. $=$ No clot

$0.45 \mathrm{ml}$ with Tris-HCl buffer. The capacity of these samples to clot on the addition of $0.05 \mathrm{ml}$ of the thrombin solution was then observed, clotting times being recorded, and any marked abnormality of clot strength noted. The results of these experiments are given in Table I.

\section{BREAKDOWN OF FIBRIN AND FIBRINOGEN BY UROKINASE}

Fibrin clots were prepared from plasminogen-rich bovine fibrinogen and the urokinase concentrations needed to bring about their lysis in about 10, 15, and $20 \mathrm{~min}$ were determined. Clots were prepared in Tris- $\mathrm{HCl}$ buffer containing $0 \cdot 1 \mathrm{ml}$ of $1 \%(\mathrm{w} / \mathrm{v})$ fibrinogen and 5 units of thrombin in a total volume of $0.5 \mathrm{ml}$; various amounts of urokinase were included and the exact clot lysis times were measured at $37^{\circ}$. The breakdown of plasminogen-rich fibrinogen by similar concentrations of urokinase was next studied. Tubes containing $0.1 \mathrm{ml}$ of the same $1 \%$ fibrinogen solution in a total volume of $0.45 \mathrm{ml}$ were incubated at $37^{\circ}$ with various amounts of urokinase. By observing the capacity of the incubated samples to clot when $0.05 \mathrm{ml}$ of a thrombin solution was added, the breakdown of fibrinogen could be detected. It was found that concentrations of urokinase sufficient to cause the lysis of a fibrin clot under these circumstances could, in the absence of thrombin, bring about the breakdown of fibrinogen to non-clottable fragments at a similar rate. These results are also summarized in Table I.

DEVELOPMENT OF FIBRIN BREAKDOWN

PRODUCTS FOLLOWING THE INCUBATION OF PLASMA CLOTS AND OF UNCLOTTED PLASMA WITH UROKINASE

To $4 \times 0.60 \mathrm{ml}$ portions of citrated human plasma was added $0.14 \mathrm{ml}$ of a solution of urokinase in buffer $(400 \mathrm{u} / \mathrm{ml})$; they were then clotted with $0.1 \mathrm{ml}$ of a solution of thrombin $(200 \mathrm{u} / \mathrm{ml})$. The clots were incubated at $37^{\circ}$ and clot lysis occurred in approximately $16 \mathrm{~min}$; the tubes were transferred to an ice bath after $7 \cdot 5,15,30$, and $60 \mathrm{~min}$. Immediately after removal of each tube from the incubator, $0.1 \mathrm{ml}$ of a solution of soya bean trypsin inhibitor $(0.5 \mathrm{mg} / \mathrm{ml}$ in $0.5 \mathrm{M}$ EACA) was added and any residual clot was synergized. After storage overnight at $+2^{\circ}$, traces of fibrin were removed and the serum samples were assayed for the content of fibrin breakdown products. In the same experiment, $3.0 \mathrm{ml}$ of plasma was mixed with $0.7 \mathrm{ml}$ of the same urokinase solution and was incubated at $37^{\circ}$. Portions $(0.6 \mathrm{ml})$ were transferred at $7 \cdot 5,15,30$, and $60 \mathrm{~min}$ to tubes each containing $0.1 \mathrm{ml}$ of a solution of thrombin, soya bean trypsin inhibitor, and EACA. Clotting was allowed to continue for $60 \mathrm{~min}$ at room temperature; the fibrin was then removed and the

\begin{tabular}{|c|c|c|c|c|}
\hline \multirow[t]{3}{*}{$\begin{array}{l}\text { Incubation } \\
\text { Time (min) }\end{array}$} & \multirow{2}{*}{\multicolumn{2}{|c|}{$\begin{array}{l}\text { Human Plasma + } \\
\text { Urokinase } \\
\text { FBP }(\mu g / m l) \\
\text { Produced by }\end{array}$}} & \multirow{2}{*}{\multicolumn{2}{|c|}{$\begin{array}{l}\text { Monkey Plasma }+ \\
\text { Urokinase } \\
\text { FBP }(\mu g / m l) \\
\text { Produced by }\end{array}$}} \\
\hline & & & & \\
\hline & $\begin{array}{l}\text { Plasma } \\
\text { Clots }^{1}\end{array}$ & $\begin{array}{l}\text { Non-clotted } \\
\text { Plasma }\end{array}$ & $\begin{array}{l}\text { Plasma } \\
\text { Clots }^{2}\end{array}$ & $\begin{array}{l}\text { Non-clotted } \\
\text { Plasma }\end{array}$ \\
\hline $\begin{array}{l}7 \cdot 5 \\
15 \\
30 \\
60\end{array}$ & $\begin{array}{r}<2 \\
500 \\
>1000 \\
>1000\end{array}$ & $\begin{array}{l}<2 \\
<2 \\
<2 \\
<2\end{array}$ & $\begin{array}{r}<2 \\
200 \\
>1000 \\
200^{3}\end{array}$ & $\begin{array}{l}<2 \\
<2 \\
<2 \\
<2\end{array}$ \\
\hline
\end{tabular}

Table II Development of fibrin breakdown products following incubation of human and monkey plasma and plasma clots with urokinase

${ }^{1}$ Clots lysed in $16 \mathrm{~min}$

${ }^{2}$ Clots lysed in $14 \mathrm{~min}$

${ }^{3}$ Poor reaction with Fi-test 
serum samples were allowed to stand overnight at $+2^{\circ}$. After removal of any further traces of fibrin, the sera were assayed for fibrin breakdown products.

A similar experiment was performed with citrated monkey plasma: $0.08 \mathrm{ml}$ of a urokinase solution $(750 \mathrm{u} / \mathrm{ml})$ was added to each aliquot of plasma $(0.6 \mathrm{ml})$, giving rise to a clot lysis time of approximately $14 \mathrm{~min}$, and $0.4 \mathrm{ml}$ of the same solution was added to $3.0 \mathrm{ml}$ of plasma in the second part of the experiment. In all other particulars the experiments with human and monkey plasmas were identical. The results of both are given in Table II.

\section{HUMAN EXERCISE STUDY}

Blood samples were collected from three male subjects $5 \mathrm{~min}$ before, and 2,30 , and $60 \mathrm{~min}$ after vigorous exercise on a stationary bicycle, lasting six minutes. The subjects, all aged approximately $\mathbf{4 0}$ years, were rested for $45 \mathrm{~min}$ before the experiment, and between the collection of the last three blood samples. The blood was transferred to plastic containers in an ice bath; duplicate samples were then quickly removed for the dilute blood clot lysis assay and $0.9 \mathrm{ml}$ portions were added to $0.1 \mathrm{ml}$ of soya bean trypsin inhibitor-thrombin solution in order to provide serum for the estımations of fibrin breakdown products. The results of these assays are shown in Table III. They show that a marked increase in fibrinolytic activity in these subjects is accompanied by only a very small and transient rise in fibrin breakdown products.

\section{STUDIES IN MONKEYS}

Administration of urokinase

Two Rhesus monkeys both weighing approximately $3.2 \mathrm{~kg}$ were tranquillized with Sernylan and cannulated. Blood samples were removed at intervals before and after the rapid intravenous administration of urokinase dissolved in sterile isotonic saline. One monkey received 12000 units of urokinase (approx. $3580 \mathrm{u} / \mathrm{kg}$ ), the other 23400 units (approx $7650 \mathrm{u} / \mathrm{kg}$ ). Blood samples were tested for fibrinolytic activity (dilute blood clot lysis time assay) and serum samples were prepared in the presence of soya bean trypsin inhibitor for the estimation of concentrations of fibrin breakdown products. The results of the assays are given in Table IV, and clearly show the development of a pronounced 'fibrinolytic' state without the appearance of fibrin breakdown products in the blood.

\section{Administration of thrombin}

Two Rhesus monkeys (4.4 and $3.0 \mathrm{~kg})$ were tranquillized with Sernylan and cannulated, and an

Time before ( - ) or after ( + ) Exercise ( $\mathrm{min})$

Subject Number

\begin{tabular}{|c|c|c|c|c|c|c|}
\hline & & & & & & \\
\hline & \multicolumn{2}{|l|}{1} & \multicolumn{2}{|l|}{2} & \multicolumn{2}{|l|}{3} \\
\hline & $\begin{array}{l}\text { DBCLT } \\
\text { (min) }\end{array}$ & $\begin{array}{l}F B P \\
(\mu g / m l)\end{array}$ & $\begin{array}{l}\underset{\text { (min) }}{\mathrm{DBCLT}} \\
\end{array}$ & $\begin{array}{l}F B P \\
(\mu g / m l)\end{array}$ & $\begin{array}{l}\text { DBCLTT } \\
\text { (min) }\end{array}$ & $\begin{array}{l}F B P \\
(\mu g / m l)\end{array}$ \\
\hline $\begin{array}{l}-5 \\
+2 \\
+30 \\
+60\end{array}$ & $\begin{array}{r}240 \\
52 \\
162 \\
225\end{array}$ & $\begin{array}{l}3 \\
6 \\
3 \\
3\end{array}$ & $\begin{array}{l}450 \\
143 \\
378 \\
355\end{array}$ & $\begin{array}{l}3 \\
6 \\
3 \\
3\end{array}$ & $\begin{array}{r}203 \\
31 \\
133 \\
180\end{array}$ & $\begin{array}{r}<1 \\
2 \\
1 \\
1\end{array}$ \\
\hline
\end{tabular}

Table III Effect of exercise on fibrinolysis (DBCLT) and on serum FBP concentration in three adult human subjects

\begin{tabular}{|c|c|c|c|c|c|}
\hline \multicolumn{3}{|c|}{ Experiment 1: Urokinase: $3600 \mathrm{u} / \mathrm{kg}$} & \multicolumn{3}{|c|}{ Experiment 2: Urokinase: $7600 \mathrm{u} / \mathrm{kg}$} \\
\hline $\begin{array}{l}\text { Time before }(-) \text { or after }(+) \\
\text { Urokinase Infusion (min) }\end{array}$ & $\begin{array}{l}D B C L T \\
(\min )\end{array}$ & $\begin{array}{l}F B P \\
(\mu g / m l)\end{array}$ & $\begin{array}{l}\text { Time before }(-) \text { or after }(+) \\
\text { Urokinase Infusion }(\text { min) }\end{array}$ & $\begin{array}{l}D B C L T \\
(\min )\end{array}$ & $\begin{array}{l}F B P \\
(\mu g / m l)\end{array}$ \\
\hline $\begin{array}{r}-36 \\
-8 \\
+10 \\
+36 \\
+65 \\
+125\end{array}$ & $\begin{array}{r}>300 \\
>300 \\
49 \\
48 \\
45 \\
270\end{array}$ & $\begin{array}{l}<2 \\
<2 \\
<2 \\
<2 \\
<2 \\
<2\end{array}$ & $\begin{array}{l}-25 \\
-11 \\
+2 \\
+10 \\
+29 \\
+56\end{array}$ & $\begin{array}{r}190 \\
250 \\
8 \\
20 \\
54 \\
26\end{array}$ & $\begin{array}{l}<2 \\
<2 \\
<2 \\
<2 \\
<2 \\
<2\end{array}$ \\
\hline
\end{tabular}

Table IV Administration in vivo of urokinase to monkeys: DBCLT and FBP assays

\begin{tabular}{|c|c|c|c|c|c|c|c|}
\hline Time before $(-)$ or after $(+)$ Throm & bin Infusion (min) & -10 & +1 & +10 & +30 & +60 & +90 \\
\hline Serum concentration of FBP $(\mu \mathrm{g} / \mathrm{ml})$ & $\begin{array}{l}\text { Experiment } 1 \\
\text { Experiment } 2\end{array}$ & $\begin{array}{l}\mathbf{0} \\
\mathbf{0}\end{array}$ & $\begin{array}{l}\mathbf{0} \\
\mathbf{0}\end{array}$ & $\begin{array}{l}450 \\
600\end{array}$ & $\begin{array}{l}450 \\
600\end{array}$ & $\begin{array}{l}600 \\
600\end{array}$ & $\begin{array}{l}600 \\
600\end{array}$ \\
\hline
\end{tabular}

Table V Administration in vivo of thrombin to monkeys $(200 \mathrm{u} / \mathrm{kg})$ : serum FBP concentration 
intravenous saline drip was set up. Blood samples were removed at intervals before and after the administration of thrombin $(200 \mathrm{u} / \mathrm{kg})$, which was infused over a period of about three minutes. Of each blood sample, $0.9 \mathrm{ml}$ was added to $0.1 \mathrm{ml}$ of soya bean trypsin inhibitor-thrombin solution and the resulting serum was collected and assayed for concentration of fibrin breakdown products. The results (Table V) show the presence of fibrin breakdown products in the serum of both animals, in high concentration.

\section{Discussion}

The results of the in vitro experiments described in this paper (Tables I-III) demonstrate that the addition of a plasminogen activator to plasma, in sufficient quantity to give rise to the rapid lysis of the clot which forms when coagulation has taken place, does not cause substantial breakdown of the fibrinogen in the unclotted plasma. This observation, which was equally valid with human and monkey plasma, accords with the findings of Niléhn (1967) who investigated the streptokinase-induced breakdown of fibrinogen and fibrin in human plasma.

The results in Table $I$ show that the clottability of monkey plasma was not affected, and that of human plasma only slightly impaired, when these plasmas were incubated with urokinase for periods several times longer than those needed for clot lysis to take place following clot formation by the addition of thrombin. This observation is substantiated by the results in Table II, which show that no breakdown products could be detected when plasma was incubated with urokinase, in contrast to the situation where the serum from plasma clotted in the presence of the same amount of urokinase was assayed. In this situation little or no breakdown product appeared until clot lysis was well advanced: at and after this stage, high concentrations were detected in both the human and monkey systems, the end point of the titrations with Fi-test reagent being at similar dilutions to that with untreated plasma. With the clot digests from monkey plasma, however, it was noticed that the titre of breakdown products appeared to be reduced after prolonged incubation, suggesting that the lower molecular weight polypeptides released from monkey fibrin do not react so efficiently with the Fi-test reagent as does the parent fibrinogen molecule. That the protection of plasma fibrinogen from breakdown by combinations of plasminogen and urokinase is related to the presence of inhibitors of fibrinogenolysis, and not simply to structural differences between the two substrates (fibrinogen and fibrin) was indicated by their equally rapid proteolysis in puri- fied systems where the inhibitors were absent (Table I). However, the possibility cannot be entirely discounted that small amounts of fibrinogen breakdown products, in insufficient concentration to modify the rate of clot formation, might be incorporated into the clot structure and thus escape detection in the serum.

The relevance of this evidence in vitro to the situation in vivo is obvious. It was anticipated that the development of a fibrinolytic state in vivo by the release of plasminogen activator into the circulation would not give rise to the destruction of fibrinogen or to the appearance of breakdown products in the blood, unless the lytic condition was accompanied or preceded by fibrin deposition. This inference was of course based on the assumption that urokinase behaves in a similar manner to the intrinsic plasminogen activator in the blood. Apart from the observations of Fearnley et al (1969), high serum concentrations of breakdown products have not been encountered in response to the induction of a fibrinolytic state in healthy subjects (see, eg, Das et al, 1967; Gormsen and Vad, 1970) in conditions where the blood has been allowed to clot in the presence of a protease inhibitor. However, elevated levels of fibrin breakdown products have been recognized in conditions where fibrin deposition is believed to have occurred, such as rheumatoid arthritis, myocardial infarction, and most markedly in the consumption coagulopathies that may develop with obstetrical complications (Ferreira and Murat, 1963; Bonnar et al, 1969). Our results with human volunteers (Table III) support the findings of Das and of Gormsen and show that the production of a vigorous fibrinolytic state in normal subjects, indicated by a fall in dilute blood clot lysis time to less than a third of the resting value, is accompanied by the appearance of only a very small $(2-3 \mu \mathrm{g} / \mathrm{ml})$ and short-lived release of breakdown products. Even this small amount of breakdown product may be a consequence of coagulation occurring as the primary response to exercise (Konttinen, 1968) rather than of the lysis of pre-existing fibrin deposits. A similarly pronounced fibrinolytic state in monkeys induced by infusion of urokinase also failed to liberate measurable amounts of breakdown products (Table IV), although in these animals the fibrinolytic state was of longer duration than that produced in the human subjects.

The capacity of the procedure to detect fibrin breakdown products in the blood samples taken from monkeys was amply confirmed by the response evoked to the infusion of thrombin. The results (Table V) show that in these circumstances intravascular coagulation was rapidly followed by the appearance of high concentrations of circulating 
fibrin breakdown products in the blood. It has been established from other experiments with ${ }^{125}$ Ilabelled fibrinogen that infusion of thrombin into monkeys as described above causes pronounced defibrination and the rapid reappearance of labelled material in the blood.

Two main inferences may be drawn from these observations: first that the provision of sufficient urokinase to activate the fibrinolytic system in vitro or in vivo does not lead to the breakdown of a significant amount of plasma fibrinogen, and second, that normal animals and healthy human subjects have little or no intravascular or other accessible fibrin that can be used as a substrate by proteolytic enzymes developed during fibrinolytic episodes.

We thank Mr C. S. Good, FRCS, and Mr D. Coombey who dosed and bled the monkeys, and the staff of the Medical Centre of this Company for their cooperation in the collection of the human blood samples.

\section{References}

Bonnar, J., Davidson, J. F., Pidgeon, C. F., McNicol, G. P., and Douglas, A. S. (1969). Fibrin degradation products in normal and abnormal pregnancy and parturition. Brit. med. J., 3, 137-140.

Das, P. C., Allan, A. G. E., Woodfield, D. G., and Cash, J. D. (1967). Fibrin degradation products in sera of normal subjects. Brit. med. J., 4, 718-720.

Fearnley, G. R., Chakrabarti, R., and Evans, J. F. (1969). Fibrinolytic and defibrinating effect of phenformin plus ethyloestrenol in vivo. Lancet, 1, 910-914.

Ferreira, H. C., and Murat, L. G. (1963). An immunological method for demonstrating fibrin degradation products in serum and its use in the diagnosis of fibrinolytic states. Brit. J. Haemat., 9, 299-310.

Gallimore, M. J., and Shaw, J. T. B. (1967). Some aspects of fibrin clot lysis and its inhibition by human serum. Thrombos. Diathes. haemorrh. (Stuttg.), 18, 101-113.

Gallimore, M. J., and Shaw, J. T. B. (1969). The influence of various plasma components on the lysis of dilute human blood clots. Thrombos. Diathes. haemorrh. (Stuttg.), 22, 223-233.

Gormsen, J., and Vad, A. (1970). Fibrinolytic activity and haemagglutination inhibition immunoassays. Scand. J. Haemat., 7, 261-273.

Konttinen, Y. P. (1968). Fibrinolysis: Chemistry, Physiology, Pathology and Clinics, p. 193. Oy STAR Ab, Pharmaceutical Manufacturers, Tampere, Finland.

Melliger, E. J. (1970). Detection of fibrinogen degradation products by use of antibody coated latex particles. Thrombos. Diathes. haemorrh. (Stuttg.), 23, 211-227.

Merskey, C., Kleiner, G. J., and Johnson, A. J. (1966). Quantitative estimation of split products of fibrinogen in human serum, relation to diagnosis and treatment. Blood, 28, 1-18.

Nilehn, J. E. (1967). Separation and estimation of split 'products' of fibrinogen and fibrin in human serum. Thrombos. Diathes. haemorrh. (Stuttg.), 18, 487-498.

Thomas, D. P., Niewiarowski, S., Myers, A. R., Block, K. J., and Colman, R. W. (1970). A comparative study of four methods for detecting fibrinogen degradation products in patients with various diseases. New Engl. J. Med., 283, 663-668. 